\title{
Gene therapy in interventional pulmonology: Interferon gene delivery with focus on thoracic malignancies
}

\author{
Satish Kalanjeri • Daniel H. Sterman
}

Published online: 8 February 2012

(C) Springer Science+Business Media, LLC 2012

\begin{abstract}
Gene therapy is a promising treatment for a variety of human diseases - particularly for malignancies - but has not been implemented into routine clinical use because sufficient delivering of therapeutic genes to effectively kill large numbers of cancer cells has proved daunting. Recently, researchers have been focusing on a method called immunogene therapy, which transfers genetic material-such as genes encoding for interferons - to trigger the patient's own immune system to fight the cancer. Mesothelioma is a particularly good target for gene therapy, because no individual treatment (surgery, chemotherapy, and/or radiation) has proven efficacious, and because mesothelioma tends to remain localized until the late stages of the disease. Even immuno-gene therapy is limited in its ability to destroy large tumors, which is why researchers are investigating combination approaches that combine traditional therapies such as surgery and chemotherapy with immunotherapy.
\end{abstract}

Keywords Interferon - Gene transfer - Adenovirus · Intrapleural · Mesothelioma · Immunotherapy ·

Interventional pulmonology

S. Kalanjeri

Division of Pulmonary and Critical Care Medicine,

Memorial Sloan-Kettering Cancer Center,

1275 York Avenue,

New York, NY 10065, USA

D. H. Sterman $(\bowtie)$

Section of Interventional Pulmonary and Thoracic Oncology, Pulmonary, Allergy and Critical Care Division,

University of Pennsylvania Medical Center,

3400 Spruce Street,

Philadelphia, PA 19104-4287, USA

e-mail: daniel.sterman@uphs.upenn.edu

\section{Introduction}

Interferons (IFNs) are a class of cytokines that have immunomodulatory effects on macrophage function, antibody production, delayed hypersensitivity reaction, and have anti-viral effects $[1 \cdot 2]$. IFNs have also been shown to have anti-proliferative effects $[1 \bullet, 2]$. The use of interferons for the treatment of tumors and infections has been studied with varied success. A major limitation in the clinical use of IFNs has been toxic systemic effects and the lack of sustained levels in tissues. The rationale for immunogene therapies such as interferon gene transfer is that transduction of specific genes in tumors and infections will result in high local expression of interferons with minimal elevations of interferon in the peripheral blood [3]. The advantage of such an approach would be to eliminate high systemic toxicity and achieve sustained and high local concentrations of therapeutic cytokines.

In this review we aim to provide the readers with a comprehensive update on the applications of gene therapy using interferon coding sequences, with particular emphasis on clinical trials of interferon genes in thoracic malignancies (Table 1).

\section{Preclinical models of interferon gene therapy for cancer}

A number of preclinical studies have shown the potential and promise of the use of interferon gene therapy in cancer. These experimental studies have demonstrated the feasibility and efficacy of this novel anti-neoplastic strategy. Early studies focused on identification of the most effective delivery systems - initially retroviral vectors [4], followed by adenoviral vectors [5]; and more recently there has been 
considerable interest in liposomal delivery systems [6, 7]. This section will discuss the potential of interferon gene therapy in preclinical models for different malignancies.

\section{Brain tumors}

Early studies on brain tumor cell lines successfully transferred genes encoding for interferon-gamma (IFN- $\gamma$ ) using a retroviral vector, and demonstrated augmentation of cytotoxic $\mathrm{T}$ lymphocytes (CTL) [4]. Intratumoral interferon-beta (IFN- $\beta$ ) expression has been studied using vectors such as herpes simplex virus [8, 9], liposomes [10], and bone marrow-derived cells [11]. Combination therapies in preclinical models have included IFN- $\beta$ gene transfer and tumor vaccination with dendritic cells, demonstrating promising results [12]. Other combination therapies for glioma have included IFN$\beta$ gene transfer with trichostatin A for neuroblastoma [13] and gamma radiation with IFN- $\beta$ gene transfer [14].

\section{Melanoma}

Initial studies of IFN- $\gamma$ gene transfer in melanoma models demonstrated enhanced expression of major histocompatibility complex (MHC) classes I and II, resulting in increased cytotoxicity [15]. A similar approach also demonstrated responses in murine models of metastatic melanoma [16]. Pretreatment of melanoma tumor cell cultures with retroviral vector-mediated interferon gene transfer followed by cisplatin therapy resulted in increased apoptosis [17]. Cationic liposome-mediated IFN- $\beta$ gene transfer has also been studied with and without radiation therapy with promising results in murine models of melanoma [18-20].

\section{Prostate cancer}

Several preclinical studies have explored the potential of interferon gene therapy for prostate cancer. Early approaches have included pretreatment of cancer cells with retroviral transfection with the IFN- $\beta$ gene and subsequent injection of these cells - as well as untreated prostate cancer cells - into mouse models, with evidence of rapid progression of nontransfected tumor compared to IFN- $\beta$ transfected cells [21]. Direct intratumoral injection of an adenoviral vector carrying the IFN- $\beta$ gene resulted in the ability to prevent tumor growth and inhibit the growth of metastatic sites, as well as to prolong the longevity of prostate tumor-bearing mice [22]. Studies with IFN- $\beta$ gene therapy have also demonstrated inhibitory effects on angiogenesis of prostate tumor cells [23] and have suggested biochemical mechanisms for tumor suppression [24]. One group of investigators utilized adenoviral vectors for IFN- $\gamma$ gene transfer with demonstration of in vitro antitumor activity [5].
Cutaneous T-cell lymphoma

Several studies have determined an imbalance in local cytokine environment in cutaneous T-cell lymphoma [25-28]. This promotes the survival of the tumor cells by viability factors such as interleukin 7 and interleukin 15 [28-30]. It has also been shown that CTCL cells also secrete T-helper 2 (Th2) cytokines such as IL-10 [26, 27, 31]. It is therefore thought that there are immunosuppressive effects such as delayed-hypersensitivity reactions, hypereosinophilia, and elevated immunoglobulin $\mathrm{E}$ ( $\mathrm{IgE}$ ) serum levels in patients with CTCL [32] and diminished natural killer (NK) cell activity [33]. Therefore, primary cutaneous lymphomas have been successfully treated clinically with recombinant IFNs, counterbalancing the Th2-skewing state [34]. The short half-lives and toxic effects of these recombinant proteins have prompted preclinical studies involving interferon gene transfer methods to elicit similar effects on tumor growth $[32,35,36]$.

Malignant pleural mesothelioma and malignant pleural effusions

It has been nearly 20 years since Smythe and colleagues at the University of Pennsylvania Medical Center first introduced replication-deficient recombinant adenovirus carrying the Escherichia coli lacZ gene into human mesothelioma cell lines. These investigators also accomplished effective gene transfer of human mesothelioma xenographs implanted within the peritoneal cavities of immunodeficient mice [37].

Nearly 10 years later, Okada and colleagues also at the University of Pennsylvania Medical Center (2001) first conducted preclinical studies investigating intracavitary delivery of a replication-deficient adenoviral vector encoding for the murine IFN- $\beta$ gene (Ad.muIFNbeta) in syngenic murine models of malignant mesothelioma [38]. This novel approach to mesothelioma provided evidence of strong CD8(+) T-cell-mediated antitumor effects. The same group also demonstrated that tumorspecific CD4+ $\mathrm{T}$ cells were also critical for in vivo tumor eradication by intracavitary interferon- $\beta$ gene transfer [39]. Kellerman et al. [40] demonstrated similar immunogenic responses in a murine mesothelioma model (AK 7) using IFN- $\gamma$ gene expression.

Kruklitis et al. [41] studied the effects of neoadjuvant immuno-gene therapy prior to surgical debulking of malignant mesothelioma in a syngeneic, immunocompetent murine model. Tumors transduced with replication-incompetent adenovirus encoding for the murine interferon- $\beta$ gene prior to surgical debulking demonstrated increased long-term tumor-free survival compared to mice who underwent tumor resection without upfront immune-gene delivery. 
Suzuki et al. [42] studied the outcome of using chemotherapy (gemcitabine) in conjunction with immuno-gene therapy using an adenovirus expressing IFN- $\beta$ in syngeneic murine models of mesothelioma and lung cancer. Significant antitumor effects were achieved with treatment of tumor-bearing mice with gemcitabine followed by administration of Ad.mu IFN- $\beta$; however, this effect was diminished in mice bearing larger tumors.

Willmon et al. [43] demonstrated an interesting approach of combining expression of IFN- $\beta$ gene and the oncolytic vesicular stomatitis virus (VSV) vector in the treatment of mesothelioma. This animal study using a mouse model concluded that the efficacy and safety of the oncolytic VSV vector is enhanced with expression of IFN- $\beta$ in tumor cell lines.

A number of studies have also evaluated the efficacy of IFN gene therapy in sarcoma [44-48], renal cell carcinoma [49-51], superficial bladder cancer [52-56], and gastrointestinal malignancies such as hepatocellular [57-61] and pancreatic carcinomas [62].

\section{Preclinical models of interferon gene therapy for infectious and inflammatory conditions}

\section{HIV}

Studies have shown inhibition of HIV replication in cell lines by incorporating IFN- $\alpha$, IFN- $\beta$, and IFN- $\gamma$ genes under the control of HIV long terminal repeat [63, 64]. Another strategy has been IFN- $\beta$ gene transduction of CD4(+) T cells to produce a continuous low-dose expression of IFN- $\beta$ in controlling HIV infection and allowing immune restoration in mouse models $[65,66]$. A comparison of interferon gene therapy and gene therapy with other modalities concluded that gene therapy using CD4 immunoadhesin was more efficient in a SCID mouse model, although expression of IFN genes did result in a marked reduction in HIV viral load [67]. More recently, lentiviral vectors containing IFN- $\beta$ sequences under the influence of the murine moderate $\mathrm{H} 2-\mathrm{kb}$ promoter have been used with success [68].

\section{Herpes simplex virus (HSV)}

Early studies showed that innate production of IFN- $\alpha$ protected mice from herpes simplex virus type 1 (HSV-1) corneal disease [69]. A series of studies by Noiskran et al. suggested the efficacy of naked plasmid DNA encoding IFN- $\alpha$ offered protection against ocular HSV-1 infection in murine models [70-72]. These promising results led to comparison of topical application of recombinant IFN- $\alpha$ to plasmid DNA encoding INF- $\alpha$ in ocular HSV-1 infection in mice [73]. There was no significant difference in efficacy for prophylaxis; however, topical application of plasmid DNA conferred advantage over recombinant IFN- $\alpha$ when applied post-infection.

Hepatitis B virus (HBV), hepatitis C virus (HCV), and cirrhosis

The success of interferon use in controlling HBV and HCV replication has led to attempts at eliciting tightly regulated tissue-specific gene expression of interferons $[74,75]$. The tetracycline-regulated (Tet) gene expression system [76, 77] has been used with success to demonstrate liver-specific expression of IFN- $\gamma$ following adenoviral gene transfer in mouse models of chronic HBV infection. This bidirectional Tet promoter system resulted in a tightly regulated 1000 fold induction of gene expression that was liver specific and effectively controlled HBV replication in mice, but did not completely eradicate the infection.

A similar approach has been adopted for $\mathrm{HCV}$ infection with injection of adenoviral vectors encoding human IFN$\alpha$ DNA (huIFN- $\alpha$ DNA) into HCV-infected hepatocyte cell lines, resulting in complete disappearance of $\mathrm{HCV}$ [78]. Another study by the same group studied adenoviral vector mediated expression of IFN- $\alpha$ in a mouse model of cirrhosis, resulting in substantial improvement in fibrotic changes [79].

\section{Western equine encephalitis virus (WEEV)}

In a murine model of WEEV, adenoviral-mediated IFN- $\alpha$ expression demonstrated the capacity for eliciting full protection against various WEEV strains when administered prophylactically, and a delayed progression of infection when given post-infection, suggesting that adenovirusmediated expression of IFN- $\alpha$ can be an alternative approach for the prevention and treatment of WEEV infection [80].

\section{Cytomegalovirus (CMV)}

The combined effect of viral DNA vaccines and IFN- $\alpha$ and IFN- $\beta$ gene transfer in murine CMV infection has been shown to be better than the partial immune response elicited by the former alone [81]. Expression of several subtypes of interferons administered by DNA inoculation has been shown to be effective in different phases of myocarditis secondary to CMV infection in mice [82].

Pulmonary tuberculosis (PTB)

Use of recombinant adenoviruses encoding murine IFN- $\gamma$ (AdIFN- $\gamma$ ) for PTB has shown to reduce the bacillary load 
in murine models for both drug-sensitive as well as multidrug-resistant (MDR) tubercular strains [83]. This offers a novel and promising approach for a disease that has significant burden on health care especially in developing countries, particularly for MDR-TB, for which standard medical therapy regimens are limited.

Hand foot and mouth disease

Studies have demonstrated complete immunization in swine by use of adenoviral vectors delivering porcine IFN- $\alpha$ genes $[84,85]$.

\section{Atherosclerosis}

While most studies have demonstrated the benefits of interferon expression for their antiviral and anti-proliferative properties, the proinflammatory effects of IFN- $\gamma$ can be counterproductive in augmenting atherosclerotic plaque formation [86]. IFN- $\gamma$ neutralization, by repeated injections of a plasmid encoding a soluble IFN- $\gamma$ construct ( $\operatorname{SIFN} \gamma$ ), has been shown to reduce lesion progression in ApoE knockout mice [87].

\section{Human clinical trials of interferon gene transfer}

\section{Melanoma}

The first clinical trial of IFN gene therapy for melanoma was conducted by Abdel-Wahab et al. [88 ], published in 1997. This phase 1 trial aimed to study the feasibility of active immunization of melanoma patients with IFN- $\gamma$ gene-modified autologous melanoma cells. Autologous melanoma cells were retrovirally transduced ex vivo with the human IFN- $\gamma$ gene to facilitate autocrine and paracrine secretion of biologically active IFN- $\gamma$. These genetically modified cells were first inactivated by irradiation and administered as immunizations to 20 melanoma patients once every 2 weeks for 3 months in a dose- escalating manner, Thirteen of the 20 patients completed the intended protocol. Humoral immunoglobin $\mathrm{G}$ ( $\operatorname{IgG}$ ) response, as measured by enzyme-linked immunoadsorbent assay (ELISA), radioimmunoassay, and radioimmunoprecipitation, was seen in eight of the 13 patients. The humoral response increased progressively with each immunization. Four patients showed clinical responses; in two of the four responding patients clinical efficacy was associated with significant increases in serum IgG response. This study suggested that autologous cellular vaccination using IFN- $\gamma$ gene transfer for patients with melanoma was safe and potentially efficacious, and induced significant and relevant humoral responses.
Nemunaitis et al. [89] conducted a phase 1 trial of direct intratumoral injection of retroviral vector encoding for human IFN- $\gamma($ huIFN- $\gamma$ ) in patients with advanced melanoma. The aim of the trial was to determine the feasibility, safety, and efficacy of such an approach. A single injection of a retroviral vector expressing huIFN- $\gamma$ was administered to 13 patients on a daily basis for 5 consecutive days. Within 1 week of dosing, 12 of the 13 patients underwent resection of the injected lesion to confirm DNA transduction in situ; 10 of these samples had viable tissue for analysis. Three of the 10 harvested tumor samples were confirmed to have IFN- $\gamma$ expression via enzyme-linked immunospot assay (ELISPOT). Interestingly, two patients (one with stage III melanoma and one with breast cancer) had no evidence of local tumor following resection of the injected lesion. No adverse events were attributed directly to the injections.

This study demonstrated the feasibility and safety of retroviral-mediated huIFN- $\gamma$ injection, with evidence of IFN- $\gamma$ expression in the tumor cells and anecdotal evidence of local tumor responses. The investigators speculated that multiple vaccinations may result in induction of superior antitumor responses.

The same investigators conducted an open-label, phase 1 inter-patient dose-escalation study to evaluate the safety and efficacy of multiple courses of retroviral-mediated huIFN- $\gamma$ vaccination [90]. Seventeen patients with metastatic melanoma were divided into six cohorts, with the first three cohorts receiving retroviral huIFN- $\gamma$ vector by intratumoral injection for 5 consecutive days. Patients in the second three cohorts were treated with the same dose levels, but were treated for six cycles - five daily injections every 2 weeks. No adverse events that could be attributed directly to the immunogene therapy were noted. Replication-competent retrovirus was not detected by polymerase chain reaction (PCR) studies. One of nine patients in the study cohort that received a single cycle of treatment achieved a $>50 \%$ response at the injected site, and the other eight had progressive disease. Three of eight patients in the treatment arm that received 6 cycles of vector injections achieved a $>50 \%$ response at the injected site, with the remainder maintaining a period of stable disease at the injected site. Median survival of single-injected patients was 150 days, while the eight patients who received multiple cycles of injections had a median survival of 369 days [91]. Overall, the study showed a benefit in clinical and immunogenic response in patients receiving multiple courses of retroviral huIFN- $\gamma$ vector injections; and the investigators recommended further studies to evaluate the optimal number of injections and duration of treatment; and also to study the effect of IFN- $\gamma$ gene transfer in conjunction with chemotherapy or other immune therapy in patients with metastatic melanoma [92].

A more recently published pilot study evaluated the role of IFN- $\beta$ gene transfer for patients with advanced 


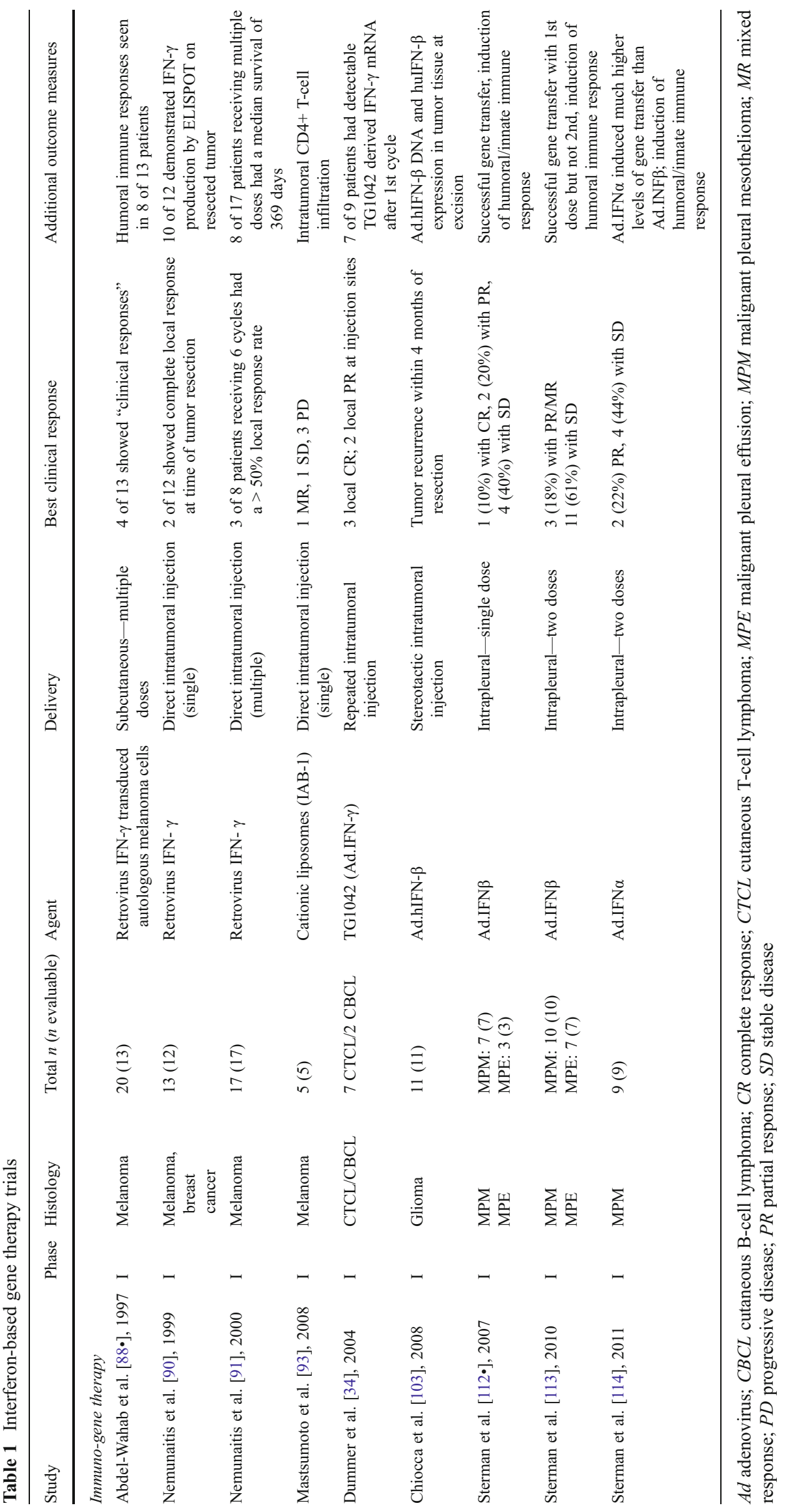


melanoma using cationic liposomes (IAB-1) to deliver the transgene [93]. Five patients were enrolled and underwent intratumoral injection of cationic liposomes containing a plasmid encoding for human interferon- $\beta$. Clinical response was evaluated according to Response Evaluation Criteria in Solid Tumors (RECIST criteria): one patient had a mixed response; one had stable disease; and three patients showed disease progression. Although clinical efficacy of IFN- $\beta$ gene transfer using cationic liposomes could not be properly assessed in this small pilot study, there were demonstrable immunological responses as evidenced by the infiltration of CD4+ T cells around tumor cells expressing HLA class II antigen associated with epidermal hyperplasia and melanoma cell apoptosis. After demonstration of safety and feasibility of this strategy in this small pilot study, the authors proposed additional studies with an increase in the number of intratumoral injections of IAB- 1 and/or the use of IFN- $\beta$ gene transfer in conjunction with administration of dendritic cells or other cytokines to enhance the anti-tumor immune response [93].

\section{Cutaneous T-cell lymphoma}

Cutaneous T-cell lymphoma (CTCL) is the most common type of primary cutaneous lymphoma, accounting for approximately $65 \%$ of cases [94]. Although there are no curative options available for CTCL, many newer treatment strategies have emerged in the past few years [32, 94, 95]. One of the newer approaches tested in human clinical trials involved intratumoral adenovirus-mediated transfer of the human IFN- $\gamma$ gene $[32,34,35,94]$.

The first human trial for the treatment of CTCL by interferon gene therapy was conducted in 2004 by Dummer et al. [34] using TG1042, a third-generation, non-replicating, adenoviral vector containing a human IFN- $\gamma$ cDNA insert. This was a phase 1 open-label, dose-escalating trial, investigating the effects of repeated intratumoral administration of TG1042 in seven patients with advanced primary CTCL and two patients with multi-lesional cutaneous B-cell lymphomas. TG1042 was injected into the target lesion once weekly for 3 weeks with no injection in the fourth week (defined as 1 treatment cycle) and thereafter up to 4 cycles, if there was no evidence of progressive disease. Most frequently reported adverse effects were injection site reaction, fatigue, fever, and headache. One patients developed severe colitis requiring hospitalization. No deaths were reported. Seven of the nine patients had detectable TG1042dervived IFN- $\gamma$ mRNA in the injected lesions after the first treatment cycle. Biopsies of the lesions showed up-regulation of CD8, TIA-1, and CAR following the TG1042 treatment. Systemic immune response such as increased serum levels of interleukin 6, IFN- $\gamma$, and neopterin (a marker for IFN- $\gamma-$ induced macrophage activity) were documented in all patients. Seven patients exhibited a significant increase in anti- adenovirus neutralizing antibodies (Nabs) after TG1042 treatment. Local tumor responses in target lesions were observed in five of the nine patients (three complete responses and two partial responses), with responses lasting from 1 to 6 months, with a median of 3 months. Based on the promising results of the above trial, Transgene initiated a phase 2 clinical trial in CBCL in 2006 [96].

\section{Malignant glioma}

Malignant glioma is an attractive target for gene therapy because it is a highly fatal, locally progressing neoplasm in a background of non-dividing cells (neurons) with rare metastasis outside of the central nervous system, thus allowing delivery of vectors into the desired site [97, 98]. Although several preclinical studies on animal models have shown promise [6, 11, 13], few clinical trials have been published using IFN gene therapy. Most clinical studies have used other gene therapy strategies such as using suicide genes [97-99] and oncolytic viruses [13, 99-101].

The first reported clinical trial of IFN gene transfer for glioma was by Eck et al. [102•], who reported the results of an open-label, inter-patient dose escalation toxicity study of adenoviral IFN- $\beta$ gene transfer in patients with recurrent or progressive malignant glioma who were undergoing surgical tumor excision. Chiocca et al. [103] subsequently evaluated the safety and biological activity of a human IFN- $\beta$ (hIFN$\beta$ )-expressing adenovirus vector (Ad.hIFN- $\beta$ ) in 11 patients with malignant glioma in a phase 1 clinical trial. Stereotactic injections of Ad.hIFN- $\beta$ were performed in a dose-escalating manner followed by surgical removal of tumor 4-8 days post vector instillation. Most of the adverse events seen were not attributed to the Ad.hIFN- $\beta$ vector except for a grade 4 confusional state in one patient. All patients had tumor recurrence within 4 months, and 10 patients died between 6 and 46 weeks after enrollment in the trial with a median survival of 17.9 weeks. Post-treatment histopathology showed evidence of dose-related induction of apoptosis of malignant glioma cells and a substantial increase in intratumoral inflammatory infiltrates. Ad.hIFN- $\beta$ DNA and huIFN- $\beta$ expression were demonstrated within tumor tissue. The study supported the safety and feasibility of such an approach with the caveat that the patient who experienced a confusional state had direct contact between Ad.hIFN- $\beta$ and CSF.

Malignant pleural mesothelioma and metastatic pleural effusions

Several clinical trials in the early 1990s demonstrated evidence of the safety and efficacy of systemic and intracavitary administration of recombinant IFN- $\alpha$, IFN- $\beta$, and IFN- $\gamma$ in patients with early-stage malignant pleural mesothelioma (MPM) [104-106]. Progress with this approach, however, 
was hampered due to problems such as drug availability, short in vivo half-life and lack of sustained tissue levels of the recombinant proteins, toxic effects of systemic administration, and limitation of demonstrable clinical effects to early-stage patients $[104,105]$.

Intrapleural IFN- $\beta$ administration for metastatic pleural effusions showed promise and reasonable safety profile, but with minimal clinical benefit, likely due to several of the same issues that limited application of recombinant type I and type II interferons in mesothelioma [106, 107]. To overcome these hurdles, a new area of interest in the past two decades has been expression of interferon(s) in tumor cells using gene transfer techniques.

The promise shown by the preclinical studies as well as human trials with other forms of immunogene therapy [108-111] led to the first human trial of interferon- $\beta$ gene therapy for MPM and MPE published in 2007 [112•]. The study, conducted at the University of Pennsylvania Medical Center, evaluated the safety and feasibility of a single-dose intrapleural IFN- $\beta$ gene transfer using an adenoviral vector (Ad.IFN- $\beta$ ) in patients with malignant pleural mesothelioma and metastatic pleural effusions. Ad.IFN- $\beta$ was administered through an indwelling pleural catheter in varying doses in two cohorts of patients-MPM (seven patients) and MPE (three patients). Subjects were evaluated for toxicity, gene transfer, immune responses, and anti-tumor responses via 18-fluorodeoxyglucose (FDG)-positron emission tomography (PET) scans and chest CT scans. Intrapleural Ad.IFN$\beta$ was generally well tolerated with transient lymphopenia as the most common side effect. Other side effects included hypoxia and liver function abnormalities. Gene transfer was documented in 7 of the 10 patients by demonstration of IFN- $\beta$ mRNA or protein expression in pleural fluid. Cytokine levels in the pleural space were highly variable at baseline and after response to gene transfer. Antitumor immune responses were demonstrated in seven of the 10 patients and included the detection of cytotoxic $\mathrm{T}$ cells (one patient), activation of circulating natural killer cells (two patients), and humoral responses to known (simian virus 40 large $\mathrm{T}$ antigen; mesothelin) and unknown tumor antigens (allogenic mesothelioma homogenates). Four of 10 patients showed meaningful clinical responses defined as disease stability and/or regression on 18-FDG PET and CT scans at day 60 after vector infusion.

This study demonstrated several important aspects of IFN gene transfer in human subjects. Firstly, administration of intrapleural Ad.IFN- $\beta$ was feasible and largely welltolerated. The maximal tolerated dose of viral particles was also determined in these 10 patients $\left(9 \times 10^{11}\right.$ viral particles). Secondly, intrapleural Ad.IFN- $\beta$ administration resulted in successful gene transfer as evidenced by the production of IFN- $\beta$ measured on ELISA of pleural fluid. Lastly, the study also demonstrated that a single intrapleural dose of IFN- $\beta$ vector was able to induce measurable antitumor immune response in most patients and anecdotal clinical responses in some patients as quantified by modified Response Evaluation Criteria in Solid Tumors (RECIST).

Encouraged by the results of a single-dose intrapleural IFN- $\beta$ gene transfer, the same group conducted a phase 1 trial at the University of Pennsylvania Medical Center to determine whether using two doses of Ad.IFN- $\beta$ vector would be superior to a single dose [113]. Ten patients with MPM and seven with MPE (underlying primary malignancies: 3 lung cancer, 2 ovarian cancer, and 2 breast cancer) received two doses of Ad.IFN- $\beta$ through an indwelling pleural catheter. Because of potential safety concerns, the trial used a dose interval of 14 days initially for 13 patients. After demonstrating no additional toxicity, the remaining four patients were treated with 7-day dosing interval. Repeated doses were generally well tolerated. The most common adverse events were lymphopenia, hypoalbuminemia, hypotension, anemia, hypocalcemia, and a mild cytokine release syndrome characterized by fever, rigors/chills, nausea, and tachycardia. Two unusual adverse effects were also detected. One of the patients developed an asymptomatic elevated partial thromboplastin time (PTT) after the first dose of vector and therefore did not receive the second dose. Subsequent investigations revealed an elevated anticardiolipin antibody level. Another patient developed pericardial tamponade and was successfully treated by therapeutic pericardiocentesis. Pericardial fluid analysis did not reveal malignant cells or IFN- $\beta$ and was negative for adenovirus testing via PCR or viral cultures [113].

In this repeat dose gene transfer study, high levels of IFN- $\beta$ were detected in pleural fluid after the first dose; however, only minimal levels were seen after the second dose. Lack of intrapleural IFN- $\beta$ expression after the second dose correlated with the rapid induction of neutralizing Ad antibodies (Nabs) within 8-14 days of initial vector instillation. Antibody responses against tumor antigens were induced in most patients. At 2 months, modified RECIST responses for the enrolled subjects were as follows: 1 partial response, 2 stable disease, 9 progressive disease, and 2 non-measurable disease. One patient died after 1 month. By PET scanning, two patients had mixed responses and 11 had stable disease. There were seven patients with survival times longer than 18 months. Overall, repeated intrapleural instillation of Ad.IFN- $\beta$ vector was safe, induced immune responses, and some evidence of clinical responses. However, rapid development of Nabs prevented effective gene transfer after the second dose, even with a dose interval as short as 7 days [113].

Based on these results, investigators at the University of Pennsylvania Medical Center planned to evaluate a shortened dosing interval by administering a second dose of Ad-IFN- $\beta$ vector 3 days after the first dose, prior to the expected peak of Nabs production. Due to withdrawal of Ad.IFN- $\beta$ vector 
supply by the industry collaborator, however, the investigators applied the above principles using a recombinant, replication incompetent adenovirus vector expressing the human interferon- $\alpha 2 b$ gene (Ad.IFN- $\alpha 2 b$ ) obtained from ScheringPlough/Merck (SCH721015) [114]. The reasoning behind this move was that the vector backbones were virtually identical and the biologic activities of both type I interferons - IFN- $\alpha$ and IFN- $\beta$ - were very similar.

Adenovirus vector expressing the human interferon- $\alpha 2 b$ gene (Ad.IFN- $\alpha 2 b$ ) was instilled on study days 1 and 4 via a tunneled pleural catheter. The first vector dose was $1 \times 10^{12}$ viral particles of Ad.hIFN- $\alpha 2 b$ (since the investigators had no experience with this new vector, for safety reasons, they chose an initial dose that was lower than the maximal tolerated dose from prior clinical trials of Ad.IFN- $\beta$ ). This dose was further reduced to $3 \times 10^{11}$ after the first three patients developed severe flu-like symptoms with the first dose of vector instillation. Subjects were assessed for antitumor responses approximately 60 days after initial treatment using CT and PET scans. Pleural fluid and serum IFN$\alpha 2 b$ levels, mesothelin-related protein (SMRP) levels, and Nabs were measured using standard techniques. If progressive disease was documented any time after 2 months, patients received other anti-tumor therapies [114].

In general, Ad.IFN- $\alpha 2 b$ vector instillation was well tolerated. Most patients developed some degree of fever and chills. High and sustained serum IFN- $\alpha$ levels were sometimes associated with protracted "flu-like symptoms" lasting 7-10 days. Pleural catheter-related infections occurred in two patients and both were treated successfully with antibiotics. No further infections were observed after the trial was amended so that subsequent patients had their pleural catheters removed the day following the second vector instillation [114].

Successful gene transfer and high levels of pleural fluid and serum IFN- $\alpha$ levels were induced, even in patients who received a lower dose of vector. Furthermore, there was evidence that the second Ad.IFN- $\alpha 2 b$ dose resulted in successful gene transfer, unlike prior trials with Ad.IFN- $\beta$. All patients had markedly increased anti-Ad Nab titers (Nabs) 1 week after Ad vector instillation; however, low levels of Nabs were measured at the time of the second vector dose (day 4). There were no increases in humoral responses to mesothelin or SV40 virus large T antigen (two defined mesothelioma-associated antigens). There were, however, other encouraging immunologic responses such as new or increased intensity bands on immunoblots containing extracts of mesothelioma cell lines in seven of eight patients, systemic NK cell activation, and up-regulation of the activation marker CD69 on circulating NK cells [114].

At the time of first radiographic assessment (60 days), three subjects had progressive disease (two had died), four had stable disease, and two had partial responses using modified RECIST criteria. Two patients had sufficient improvement that they were subsequently able to undergo successful radical pleurectomy (RP), with no signs of recurrence as of 7 and 19 months postoperatively, respectively. One patient, who has been previously treated with radical pleurectomy and chemotherapy, had a very impressive radiographic response in that many of the pleural-based malignant foci had regressed on PET/CT by 2 months after vector instillations. On 6-month follow-up PET/CT, post Ad.IFN- $\alpha 2 b$, many lesions had completely resolved, all at sites distant from vector instillation [114] (Fig. 1).
Fig. 1 PET/CT scan images pre and post intrapleural interferon$\alpha$ gene delivery in patient with recurrent mesothelioma status post prior right radical pleurectomy and intrapleural photodynamic therapy and adjuvant chemotherapy with new sites of disease in mediastinal, hilar, and peri-celiac nodes, right lateral hemithorax, and anterior mediastinum. Scans 6 months post localized intrapleural instillation of SCH721015 adenoviral interferon- $\alpha$ vector demonstrate marked regression at disease at all sites with complete resolution of 2 centimeter diameter hypermetabolic mass in the anterior mediastinum. This mass was at a site quite distant from the local area of intrapleural vector delivery
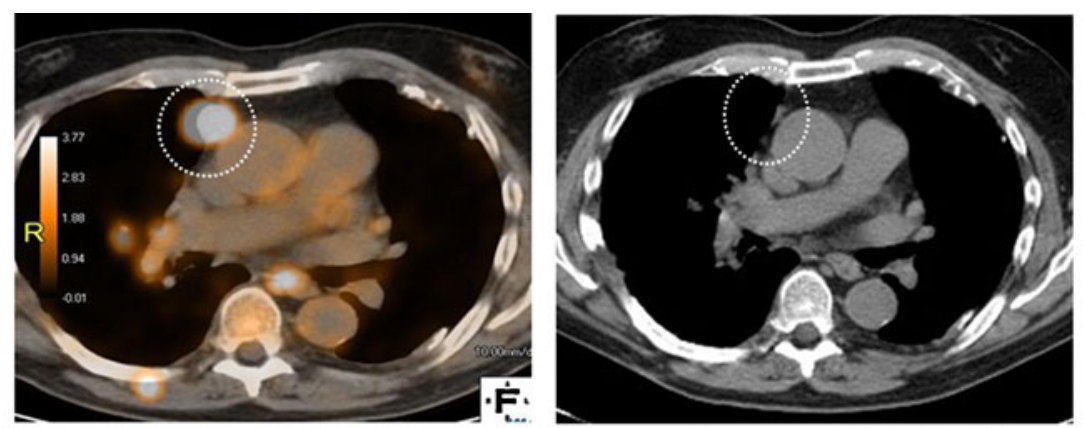

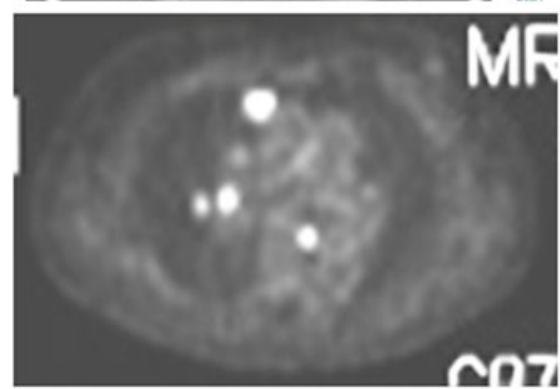

Pre Gene Therapy

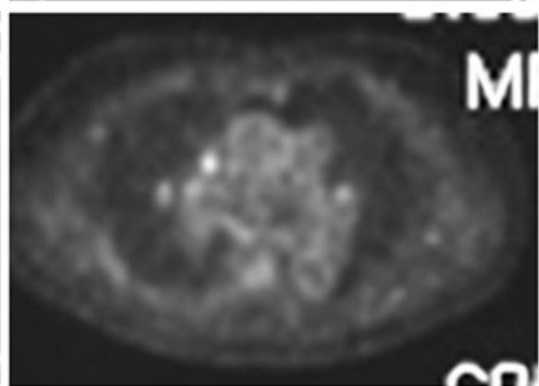

6 Months Post Gene Therapy 
Overall this study provided indirect comparison between Ad.IFN- $\alpha 2 b$ and Ad.IFN- $\beta$ vector and highlighted similarities (generally well tolerated and similar anti-tumor humoral immune responses) and differences (pleural and serum IFN- $\alpha$ concentrations were much higher at equivalent, or even lower, vector doses). It is not yet clear if the perceived higher potency of Ad.IFN- $\alpha 2 b$ translates into better antitumor activity. The most important outcome of the study was the demonstration of lower levels of Nabs at the shortened dosing interval with prolonged intrapleural expression of the interferon transgene. The combination of a better dosing strategy as above as well as the higher potency and sustained levels of IFN- $\alpha$ may result in better anti-tumor response in future clinical trials [114].

\section{Conclusions and future directions}

Interferon gene therapy is an attractive and exciting strategy in treatment of many viral infections and tumors. Better vectors, both viral and non-viral, have been developed and a fair number of clinical trials using interferon gene therapy have been attempted in a variety of malignancies. These trials have mostly documented safety, successful gene transfer, and induction of anti-tumor humoral and cellular immune responses, but showed only limited efficacy. It must be noted though that the clinical trials have used this approach after completely exhausting all available standards therapies, and therefore the patients enrolled had by definition advanced malignancies and immune systems that had been buffeted by multiple prior cycles of systemic chemotherapy. Given the complex nature of pathogenesis of many malignancies, the future may lie in combination gene therapy approaches. Use of oncolytic viruses and interferon gene transfer, for example, could improve outcome by facilitating greater expression of cytokine genes within target tumors [43]. Use of other immunostimulatory molecules such as other cytokines or even tumor vaccines could offer promising outcomes and perhaps improve efficacy of each other [115].

Multimodality cancer treatment-ie, surgical debulking, chemotherapy, and/or radiotherapy-in conjunction with interferon gene transfer may provide improved long-term outcomes. Based on preclinical trials, the group at Penn has initiated a phase 2 a clinical trial of repeated dose intrapleural Ad.IFN- $\alpha$ in combination with standard chemotherapy for patients with MPM. In addition, a neoadjuvant surgery trial involving vector administration to patients with MPM followed by maximal cytoreduction and adjuvant chemotherapy is also being planned [116].

Although it has been more than 20 years since the advent of immunogene therapy, there has been slow progress with its foray into clinical practice. However, experts in this field are increasingly optimistic about the future of immunogene therapy as a therapeutic modality, particularly in neoplastic diseases $[116,117]$.

Disclosure No potential conflicts of interest relevant to this article were reported.

\section{References}

Papers of particular interest, published recently, have been highlighted as:

- Of importance

1. - Pestka S, Langer JA, Zoon KC, Samuel CE. Interferons and their actions. Annu Rev Biochem 1987;56:727-777. This paper offers an excellent review of the interferons and their biological functions in vivo.

2. Pestka S. The interferons: 50 years after their discovery, there is much more to learn. J Biol Chem. 2007;282(28):20047-51.

3. Iqbal Ahmed CM, Johnson HM. Interferon gene therapy for the treatment of cancer and viral infections. Drugs Today Barc. 2003;39(10):763-6.

4. Nishihara K. A novel experimental approach to immunotherapy against malignant brain tumor with the mouse IFN-gamma gene transfer. Nippon Geka Hokan. 1989;58(1):18-42.

5. Zhao P, Zhu YH, Wu JX, Liu RY, Zhu XY, Xiao X, et al. Adenovirus-mediated delivery of human IFNgamma gene inhibits prostate cancer growth. Life Sci. 2007;81(9):695-701.

6. Kanno H, Hattori S, Sato H, Murata H, Huang FH, Hayashi A, et al. Experimental gene therapy against subcutaneously implanted glioma with a herpes simplex virus-defective vector expressing interferon-gamma. Cancer Gene Ther. 1999;6(2):147-54.

7. Natsume A, Mizuno M, Ryuke Y, Yoshida J. Antitumor effect and cellular immunity activation by murine interferon-beta gene transfer against intracerebral glioma in mouse. Gene Ther. 1999;6 (9):1626-33.

8. Wakabayashi T, Mizuno M, Yoshida J. The effectiveness of interferon-beta against glioma cells and its augmentation of growth inhibitory effect by transfection of its gene. Hum Cell. 1995;8(3):95-8.

9. Saleh M, Jonas NK, Wiegmans A, Stylli SS. The treatment of established intracranial tumors by in situ retroviral IFN-gamma transfer. Gene Ther. 2000;7(20):1715-24.

10. Yagi K, Ohishi N, Hamada A, Shamoto M, Ohbayashi M, Ishida $\mathrm{N}$, et al. Basic study on gene therapy of human malignant glioma by use of the cationic multilamellar liposome-entrapped human interferon beta gene. Hum Gene Ther. 1999;10(12):1975-82.

11. Makar TK, Wilt S, Dong Z, Fishman P, Mouradian MM, DhibJalbut $\mathrm{S}$. IFN-beta gene transfer into the central nervous system using bone marrow cells as a delivery system. J Interferon Cytokine Res. 2002;22(7):783-91.

12. Saito R, Mizuno M, Nakahara N, Tsuno T, Kumabe T, Yoshimoto $\mathrm{T}$, et al. Vaccination with tumor cell lysate-pulsed dendritic cells augments the effect of IFN-beta gene therapy for malignant glioma in an experimental mouse intracranial glioma. Int $\mathrm{J}$ Cancer. 2004;111(5):777-82.

13. Hamner JB, Sims TL, Cutshaw A, Dickson PV, Rosati S, McGee $\mathrm{M}$, et al. The efficacy of combination therapy using adenoassociated virus-interferon beta and trichostatin $\mathrm{A}$ in vitro and 
in a murine model of neuroblastoma. J Pediatr Surg. 2008;43 (1):177-82. discussion 182-3.

14. Tatsuta K, Tanaka S, Tajiri T, Shibata S, Komaru A, Ueda Y, et al. Complete elimination of established neuroblastoma by synergistic action of gamma-irradiation and DCs treated with $\mathrm{rSeV}$ expressing interferon-beta gene. Gene Ther. 2009;16(2):240-51.

15. Abdel-Wahab ZA, Osanto S, Darrow TL, Barber JR, Vervaert CE, Gangavalli R, et al. Transduction of human melanoma cells with the gamma interferon gene enhances cellular immunity. Cancer Gene Ther. 1994;1(3):171-9.

16. Abdel-Wahab Z, Dar M, Osanto S, Fong T, Vervaert CE, Hester D, et al. Eradication of melanoma pulmonary metastases by immunotherapy with tumor cells engineered to secrete interleukin-2 or gamma interferon. Cancer Gene Ther. 1997;4 (1):33-41.

17. Mecchia M, Matarrese P, Malorni W, D'Agostino G, Sestili P, Santini SM, et al. Type I consensus interferon (CIFN) gene transfer into human melanoma cells up-regulates p53 and enhances cisplatin-induced apoptosis: implications for new therapeutic strategies with IFN-alpha. Gene Ther. 2000;7(2):167-79.

18. Kageshita T, Mizuno M, Ono T, Matsumoto K, Saida T, Yoshida J. Growth inhibition of human malignant melanoma transfected with the human interferon-beta gene by means of cationic liposomes. Melanoma Res. 2001;11(4):337-42.

19. Ryuke Y, Mizuno M, Natsume A, Suzuki O, Nobayashi M, Kageshita T, et al. Growth inhibition of subcutaneous mouse melanoma and induction of natural killer cells by liposomemediated interferon-beta gene therapy. Melanoma Res. 2003;13 (4):349-56.

20. Wu CM, Li XY, Huang TH. Anti-tumor effect of pEgrIFNgamma gene-radiotherapy in B16 melanoma-bearing mice. World J Gastroenterol. 2004;10(20):3011-5.

21. Dong Z, Greene G, Pettaway C, Dinney CP, Eue I, Lu W, et al. Suppression of angiogenesis, tumorigenicity, and metastasis by human prostate cancer cells engineered to produce interferon-beta. Cancer Res. 1999;59(4):872-9.

22. Zhang F, Lu W, Dong Z. Tumor-infiltrating macrophages are involved in suppressing growth and metastasis of human prostate cancer cells by INF-beta gene therapy in nude mice. Clin Cancer Res. 2002;8(9):2942-51.

23. Lee J, Wang A, Hu Q, Lu S, Dong Z. Adenovirus-mediated interferon-beta gene transfer inhibits angiogenesis in and progression of orthotopic tumors of human prostate cancer cells in nude mice. Int J Oncol. 2006;29(6):1405-12.

24. Olson MV, Lee J, Zhang F, Wang A, Dong Z. Inducible nitric oxide synthase activity is essential for inhibition of prostatic tumor growth by interferon-beta gene therapy. Cancer Gene Ther. 2006;13(7):676-85.

25. Rook AH, Gottlieb SL, Wolfe JT, Vowels BR, Sood SS, Niu Z, et al. Pathogenesis of cutaneous T-cell lymphoma: implications for the use of recombinant cytokines and photopheresis. Clin Exp Immunol. 1997;107 Suppl 1:16-20.

26. Vowels BR, Cassin M, Vonderheid EC, Rook AH. Aberrant cytokine production by Sezary syndrome patients: cytokine secretion pattern resembles murine Th2 cells. J Invest Dermatol. 1992;99(1):90-4.

27. Asadullah K, Docke WD, Haeussler A, Sterry W, Volk HD. Progression of mycosis fungoides is associated with increasing cutaneous expression of interleukin-10 mRNA. J Invest Dermatol. 1996;107(6):833-7.

28. Asadullah K, Gellrich S, Haeussler-Quade A, Friedrich M, Docke $\mathrm{WD}$, Jahn $\mathrm{S}$, et al. Cytokine expression in primary cutaneous germinal center cell lymphomas. Exp Dermatol. 2000;9(1):71-6.

29. Dalloul A, Laroche L, Bagot M, Mossalayi MD, Fourcade C, Thacker DJ, et al. Interleukin-7 is a growth factor for Sezary lymphoma cells. J Clin Invest. 1992;90(3):1054-60.
30. Dobbeling U, Dummer R, Laine E, Potoczna N, Qin JZ, Burg G. Interleukin-15 is an autocrine/paracrine viability factor for cutaneous T-cell lymphoma cells. Blood. 1998;92(1):252-8.

31. Dummer R, Heald PW, Nestle FO, Ludwig E, Laine E, Hemmi S, et al. Sezary syndrome T-cell clones display T-helper 2 cytokines and express the accessory factor-1 (interferon-gamma receptor beta-chain). Blood. 1996;88(4):1383-9.

32. Farkas A, Kemeny L, French LE, Dummer R. New and experimental skin-directed therapies for cutaneous lymphomas. Skin Pharmacol Physiol. 2009;22(6):322-34.

33. Laroche L, Kaiserlian D. Decreased natural-killer-cell activity in cutaneous T-cell lymphomas. N Engl J Med. 1983;308(2):101-2.

34. Dummer R, Hassel JC, Fellenberg F, Eichmuller S, Maier T, Slos $\mathrm{P}$, et al. Adenovirus-mediated intralesional interferon-gamma gene transfer induces tumor regressions in cutaneous lymphomas. Blood. 2004;104(6):1631-8.

35. Dummer R, Cozzio A, Meier S, Beyeler M, Laetsch B, Doebbeling U, et al. Standard and experimental therapy in cutaneous T-cell lymphomas. J Cutan Pathol. 2006;33 Suppl 1:52-7.

36. Urosevic M, Fujii K, Calmels B, Laine E, Kobert N, Acres B, et al. Type I IFN innate immune response to adenovirus-mediated IFN-gamma gene transfer contributes to the regression of cutaneous lymphomas. J Clin Invest. 2007;117(10):2834-46.

37. Smythe WR, Kaiser LR, Hwang HC, Amin KM, Pilewski JM, Eck SJ, et al. Successful adenovirus-mediated gene transfer in an in vivo model of human malignant mesothelioma. Ann Thorac Surg. 1994;57(6):1395-401.

38. Odaka M, Sterman DH, Wiewrodt R, Zhang Y, Kiefer M, Amin $\mathrm{KM}$, et al. Eradication of intraperitoneal and distant tumor by adenovirus-mediated interferon-beta gene therapy is attributable to induction of systemic immunity. Cancer Res. 2001;61 (16):6201-12.

39. Odaka M, Wiewrodt R, DeLong P, Tanaka T, Zhang Y, Kaiser L, et al. Analysis of the immunologic response generated by Ad. IFN-beta during successful intraperitoneal tumor gene therapy. Mol Ther. 2002;6(2):210-8.

40. Cordier Kellerman L, Valeyrie L, Fernandez N, Opolon P, Sabourin JC, Maubec E, et al. Regression of AK7 malignant mesothelioma established in immunocompetent mice following intratumoral gene transfer of interferon gamma. Cancer Gene Ther. 2003;10(6):481-90.

41. Kruklitis RJ, Singhal S, Delong P, Kapoor V, Sterman DH, Kaiser LR, et al. Immuno-gene therapy with interferon-beta before surgical debulking delays recurrence and improves survival in a murine model of malignant mesothelioma. J Thorac Cardiovasc Surg. 2004;127(1):123-30.

42. Suzuki E, Kapoor V, Jassar AS, Kaiser LR, Albelda SM. Gemcitabine selectively eliminates splenic Gr-1+/CD11b+ myeloid suppressor cells in tumor-bearing animals and enhances antitumor immune activity. Clin Cancer Res. 2005;11(18): 6713-21.

43. Willmon CL, Saloura V, Fridlender ZG, Wongthida P, Diaz RM, Thompson J, et al. Expression of IFN-beta enhances both efficacy and safety of oncolytic vesicular stomatitis virus for therapy of mesothelioma. Cancer Res. 2009;69(19):7713-20.

44. Shiloni E, Karp SE, Custer MC, Shilyansky J, Restifo NP, Rosenberg SA, et al. Retroviral transduction of interferongamma cDNA into a nonimmunogenic murine fibrosarcoma: generation of $\mathrm{T}$ cells in draining lymph nodes capable of treating established parental metastatic tumor. Cancer Immunol Immunother. 1993;37(5):286-92.

45. Yim JH, Wu SJ, Casey MJ, Norton JA, Doherty GM. IFN regulatory factor-1 gene transfer into an aggressive, nonimmunogenic sarcoma suppresses the malignant phenotype and enhances immunogenicity in syngeneic mice. J Immunol. 1997;158(3): 1284-92. 
46. Dong Z, Juang SH, Kumar R, Eue I, Xie K, Bielenberg D, et al. Suppression of tumorigenicity and metastasis in murine UV-2237 fibrosarcoma cells by infection with a retroviral vector harboring the interferon-beta gene. Cancer Immunol Immunother. 1998;46 (3): $137-46$.

47. Lu W, Fidler IJ, Dong Z. Eradication of primary murine fibrosarcomas and induction of systemic immunity by adenovirusmediated interferon beta gene therapy. Cancer Res. 1999;59 (20):5202-8.

48. Jahnke A, Hirschberger J, Fischer C, Brill T, Kostlin R, Plank C, et al. Intra-tumoral gene delivery of feIL-2, feIFN-gamma and feGM-CSF using magnetofection as a neoadjuvant treatment option for feline fibrosarcomas: a phase-I study. J Vet Med A Physiol Pathol Clin Med. 2007;54(10):599-606.

49. Mendiratta SK, Quezada A, Matar M, Thull NM, Bishop JS, Nordstrom JL, et al. Combination of interleukin 12 and interferon alpha gene therapy induces a synergistic antitumor response against colon and renal cell carcinoma. Hum Gene Ther. 2000; 11(13):1851-62.

50. Nakanishi H, Mizutani Y, Kawauchi A, Ukimura O, Shiraishi T, Hatano M, et al. Significant antitumoral activity of cationic multilamellar liposomes containing human IFN-beta gene against human renal cell carcinoma. Clin Cancer Res. 2003;9(3):1129-35.

51. Mizutani Y, Nakanishi H, Miki T, Mizuno M, Yoshida J. Gene therapy using cationic multilamellar liposomes containing human interferon-beta gene against renal cell carcinoma. Hinyokika Kiyo. 2005;51(2):71-3.

52. Hashimura T, Hiura M, Yoshida O, Teramura Y, Kuribayashi K, Watanabe Y. Cancer immunotherapy by murine bladder cancer cells transfected with mouse interferon-gamma gene. Hinyokika Kiyo. 1993;39(12):1205-8.

53. Hashimura T, Ueda T, Hiura M, Yoshida O, Kawabata K, Watanabe $\mathrm{Y}$, et al. Gene therapy by in vivo interferon-gamma gene transfer to murine bladder tumor. Hinyokika Kiyo. 1997;43 (11):809-13.

54. Izawa JI, Sweeney P, Perrotte P, Kedar D, Dong Z, Slaton JW, et al. Inhibition of tumorigenicity and metastasis of human bladder cancer growing in athymic mice by interferon-beta gene therapy results partially from various antiangiogenic effects including endothelial cell apoptosis. Clin Cancer Res. 2002;8(4):1258-70.

55. Shiau AL, Lin CY, Tzai TS, Wu CL. Postoperative immuno-gene therapy of murine bladder tumor by in vivo administration of retroviruses expressing mouse interferon-gamma. Cancer Gene Ther. 2001;8(1):73-81.

56. Nagabhushan TL, Maneval DC, Benedict WF, Wen SF, Ihnat PM, Engler H, et al. Enhancement of intravesical delivery with Syn3 potentiates interferon-alpha2b gene therapy for superficial bladder cancer. Cytokine Growth Factor Rev. 2007;18(5-6):389-94.

57. Wang J, Cao X, Kong X. Experimental study on the treatment of human hepatocellular carcinoma by fibroblast-mediated human IFN-alpha gene therapy in combination with adoptive chemoimmunotherapy. Zhonghua Zhong Liu Za Zhi. 1995;17 (4):266-70.

58. He LF, Gu JF, Tang WH, Fan JK, Wei N, Zou WG, et al. Significant antitumor activity of oncolytic adenovirus expressing human interferon-beta for hepatocellular carcinoma. J Gene Med. 2008;10(9):983-92.

59. Huang KW, Huang YC, Tai KF, Chen BH, Lee PH, Hwang LH. Dual therapeutic effects of interferon-alpha gene therapy in a rat hepatocellular carcinoma model with liver cirrhosis. Mol Ther. 2008;16(10):1681-7.

60. Diez S, Navarro G, de ILarduya CT. In vivo targeted gene delivery by cationic nanoparticles for treatment of hepatocellular carcinoma. J Gene Med. 2009;11(1):38-45.

61. Tan XH, Zhu Q. Synergic effect of adenoviral vector-encoding human alpha-fetoprotein and interferon-gamma on immunity against hepatocellular carcinoma in mice. Ai Zheng. 2008;27 (2):155-9

62. Ziske C, Nagaraj S, Marten A, Gorschluter M, Strehl J, Sauerbruch T, et al. Retroviral IFN-alpha gene transfer combined with gemcitabine acts synergistically via cell cycle alteration in human pancreatic carcinoma cells implanted orthotopically in nude mice. J Interferon Cytokine Res. 2004;24(8):490-6.

63. Bednarik DP, Mosca JD, Raj NB, Pitha PM. Inhibition of human immunodeficiency virus (HIV) replication by HIV-trans-activated alpha 2-interferon. Proc Natl Acad Sci U S A. 1989;86(13): 4958-62.

64. Leissner P, Calenda V, Marigliano M, Sanhadji K, Touraine JL, Pavirani A, et al. In vitro and in vivo inhibition of HIV1 replication by retroviral transfer of interferon alpha, beta, or gamma genes: application to gene therapy of AIDS. Ann Biol Clin Paris. 1998;56(2):167-73.

65. Vieillard V, Jouveshomme S, Leflour N, Jean-Pierre E, Debre P, De Maeyer E, et al. Transfer of human CD4(+) T lymphocytes producing beta interferon in Hu-PBL-SCID mice controls human immunodeficiency virus infection. J Virol. 1999;73(12):10281-8.

66. Vieillard V, Lauret E, Rousseau V, De Maeyer E. Blocking of retroviral infection at a step prior to reverse transcription in cells transformed to constitutively express interferon beta. Proc Natl Acad Sci U S A. 1994;91(7):2689-93.

67. Touraine JL, Sanhadji K, Sembeil R. Gene therapy for human immunodeficiency virus infection in the humanized SCID mouse model. Isr Med Assoc J. 2003;5(12):863-7.

68. Brule F, Khatissian E, Benani A, Bodeux A, Montagnier L, Piette J, et al. Inhibition of HIV replication: a powerful antiviral strategy by IFN-beta gene delivery in CD4+ cells. Biochem Pharmacol. 2007;74(6):898-910.

69. Hendricks RL, Weber PC, Taylor JL, Koumbis A, Tumpey TM, Glorioso JC. Endogenously produced interferon alpha protects mice from herpes simplex virus type 1 corneal disease. J Gen Virol 1991;72(Pt 7)(Pt 7):1601-1610.

70. Noisakran S, Carr DJ. Plasmid DNA encoding IFN-alpha 1 antagonizes herpes simplex virus type 1 ocular infection through $\mathrm{CD} 4+$ and CD8+ T lymphocytes. J Immunol. 2000;164(12):6435-43.

71. Noisakran SJ, Carr DJ. Therapeutic efficacy of DNA encoding IFN-alpha1 against corneal HSV-1 infection. Curr Eye Res. 2000;20(5):405-12.

72. Noisakran S, Campbell IL, Carr DJ. Ectopic expression of DNA encoding IFN-alpha 1 in the cornea protects mice from herpes simplex virus type 1-induced encephalitis. J Immunol. 1999;162 (7):4184-90.

73. Noisakran S, Carr DJ. Topical application of the cornea postinfection with plasmid DNA encoding interferon-alpha1 but not recombinant interferon-alphaA reduces herpes simplex virus type 1 -induced mortality in mice. J Neuroimmunol. 2001;121(12):49-58.

74. Protzer U, Nassal M, Chiang PW, Kirschfink M, Schaller H. Interferon gene transfer by a hepatitis B virus vector efficiently suppresses wild-type virus infection. Proc Natl Acad Sci U S A. 1999;96(19):10818-23.

75. Dumortier J, Schonig K, Oberwinkler H, Low R, Giese T, Bujard $\mathrm{H}$, et al. Liver-specific expression of interferon gamma following adenoviral gene transfer controls hepatitis $\mathrm{B}$ virus replication in mice. Gene Ther. 2005;12(8):668-77.

76. Gossen M, Bujard H. Efficacy of tetracycline-controlled gene expression is influenced by cell type: commentary. Biotechniques. 1995;19(2):213-6. discussion 216-7.

77. Gossen M, Bujard H. Tight control of gene expression in mammalian cells by tetracycline-responsive promoters. Proc Natl Acad Sci U S A. 1992;89(12):5547-51.

78. Suzuki K, Aoki K, Ohnami S, Yoshida K, Kazui T, Kato N, et al. Adenovirus-mediated gene transfer of interferon alpha inhibits 
hepatitis $\mathrm{C}$ virus replication in hepatocytes. Biochem Biophys Res Commun. 2003;307(4):814-9.

79. Suzuki K, Aoki K, Ohnami S, Yoshida K, Kazui T, Kato N, et al. Adenovirus-mediated gene transfer of interferon alpha improves dimethylnitrosamine-induced liver cirrhosis in rat model. Gene Ther. 2003;10(9):765-73.

80. Wu JQ, Barabe ND, Huang YM, Rayner GA, Christopher ME, Schmaltz FL. Pre- and post-exposure protection against Western equine encephalitis virus after single inoculation with adenovirus vector expressing interferon alpha. Virology. 2007;369(1):206-13.

81. Cull VS, Broomfield S, Bartlett EJ, Brekalo NL, James CM. Coimmunisation with type I IFN genes enhances protective immunity against cytomegalovirus and myocarditis in gB DNAvaccinated mice. Gene Ther. 2002;9(20):1369-78.

82. Cull VS, Bartlett EJ, James CM. Type I interferon gene therapy protects against cytomegalovirus-induced myocarditis. Immunology. 2002;106(3):428-37.

83. Mata-Espinosa DA, Mendoza-Rodriguez V, Aguilar-Leon D, Rosales R, Lopez-Casillas F, Hernandez-Pando R. Therapeutic effect of recombinant adenovirus encoding interferon-gamma in a murine model of progressive pulmonary tuberculosis. Mol Ther. 2008;16(6):1065-72.

84. Chinsangaram J, Moraes MP, Koster M, Grubman MJ. Novel viral disease control strategy: adenovirus expressing alpha interferon rapidly protects swine from foot-and-mouth disease. J Virol. 2003;77(2):1621-5.

85. Moraes MP, Chinsangaram J, Brum MC, Grubman MJ. Immediate protection of swine from foot-and-mouth disease: a combination of adenoviruses expressing interferon alpha and a foot-and-mouth disease virus subunit vaccine. Vaccine. 2003;22 (2):268-79.

86. Gotsman I, Lichtman AH. Targeting interferon-gamma to treat atherosclerosis. Circ Res. 2007;101(4):333-4.

87. Koga M, Kai H, Yasukawa H, Yamamoto T, Kawai Y, Kato S, et al. Inhibition of progression and stabilization of plaques by postnatal interferon-gamma function blocking in ApoE-knockout mice. Circ Res. 2007;101(4):348-56.

88. - Abdel-Wahab Z, Weltz C, Hester D, Pickett N, Vervaert C, Barber JR, et al. A Phase I clinical trial of immunotherapy with interferon-gamma gene-modified autologous melanoma cells: monitoring the humoral immune response. Cancer 1997;80 (3):401-412. This paper is the first to describe human delivery of interferon genes to tumors in a clinical trial.

89. Nemunaitis J, Bohart C, Fong T, Meyer W, Edelman G, Paulson $\mathrm{RS}$, et al. Phase I trial of retroviral vector-mediated interferon (IFN)-gamma gene transfer into autologous tumor cells in patients with metastatic melanoma. Cancer Gene Ther. 1998;5 (5):292-300.

90. Nemunaitis J, Fong T, Robbins JM, Edelman G, Edwards W, Paulson RS, et al. Phase I trial of interferon-gamma (IFN-gamma) retroviral vector administered intratumorally to patients with metastatic melanoma. Cancer Gene Ther. 1999;6(4):322-30.

91. Nemunaitis J, Buchanan A, Jolly DJ. Long-term follow-up of retroviral vector-administered interferon-gamma (IFN-gamma) gene in metastatic melanoma. Cancer Gene Ther. 2000;7 (10): $1297-8$

92. Fujii S, Huang S, Fong TC, Ando D, Burrows F, Jolly DJ, et al. Induction of melanoma-associated antigen systemic immunity upon intratumoral delivery of interferon-gamma retroviral vector in melanoma patients. Cancer Gene Ther. 2000;7(9):1220-30.

93. Matsumoto K, Kubo H, Murata H, Uhara H, Takata M, Shibata S, et al. A pilot study of human interferon beta gene therapy for patients with advanced melanoma by in vivo transduction using cationic liposomes. Jpn J Clin Oncol. 2008;38(12):849-56.

94. Zinzani PL, Ferreri AJ, Cerroni L. Mycosis fungoides. Crit Rev Oncol Hematol. 2008;65(2):172-82.
95. Dummer R. Future perspectives in the treatment of cutaneous T-cell lymphoma (CTCL). Semin Oncol. 2006;33(1 Suppl 3): S33-6.

96. Urosevic M. Drug evaluation: TG-1042, an adenovirus-mediated IFNgamma gene delivery for the intratumoral therapy of primary cutaneous lymphomas. Curr Opin Investig Drugs. 2007;8 (6):493-8.

97. Lawler SE, Peruzzi PP, Chiocca EA. Genetic strategies for brain tumor therapy. Cancer Gene Ther. 2006;13(3):225-33.

98. Pulkkanen KJ, Yla-Herttuala S. Gene therapy for malignant glioma: current clinical status. Mol Ther. 2005;12(4):585-98.

99. Chiocca EA, Aghi M, Fulci G. Viral therapy for glioblastoma. Cancer J. 2003;9(3):167-79.

100. Chiocca EA. Oncolytic viruses. Nat Rev Cancer. 2002;2 (12):938-50.

101. Ehtesham M, Samoto K, Kabos P, Acosta FL, Gutierrez MA, Black KL, et al. Treatment of intracranial glioma with in situ interferon-gamma and tumor necrosis factor-alpha gene transfer. Cancer Gene Ther. 2002;9(11):925-34.

102. • Eck SL, Alavi JB, Judy K, Phillips P, Alavi A, Hackney D, et al. Treatment of recurrent or progressive malignant glioma with a recombinant adenovirus expressing human interferon-beta (H5.010CMVhIFN-beta): a phase I trial. Hum Gene Ther 2001;12(1):97-113. This paper is the first to describe delivery of interferon genes to brain tumors in humans.

103. Chiocca EA, Smith KM, McKinney B, Palmer CA, Rosenfeld S, Lillehei K, et al. A phase I trial of Ad.hIFN-beta gene therapy for glioma. Mol Ther. 2008;16(3):618-26.

104. Boutin C, Nussbaum E, Monnet I, Bignon J, Vanderschueren R, Guerin JC, et al. Intrapleural treatment with recombinant gammainterferon in early stage malignant pleural mesothelioma. Cancer. 1994;74(9):2460-7.

105. Boutin C, Viallat JR, Van Zandwijk N, Douillard JT, Paillard JC, Guerin JC, et al. Activity of intrapleural recombinant gammainterferon in malignant mesothelioma. Cancer. 1991;67(8):2033-7.

106. Cascinu S, Isidori PP, Fedeli A, Fedeli SL, Raspugli M, Rossi A, et al. Experience with intrapleural natural beta interferon in the treatment of malignant pleural effusions. Tumori. 1991;77(3): 237-8.

107. Rosso R, Rimoldi R, Salvati F, De Palma M, Cinquegrana A, Nicolo $\mathrm{G}$, et al. Intrapleural natural beta interferon in the treatment of malignant pleural effusions. Oncology. 1988;45(3):253-6.

108. Elshami AA, Kucharczuk JC, Zhang HB, Smythe WR, Hwang HC, Litzky LA, et al. Treatment of pleural mesothelioma in an immunocompetent rat model utilizing adenoviral transfer of the herpes simplex virus thymidine kinase gene. Hum Gene Ther. 1996;7(2):141-8.

109. Kucharczuk JC, Raper S, Elshami AA, Amin KM, Sterman DH, Wheeldon EB, et al. Safety of intrapleurally administered recombinant adenovirus carrying herpes simplex thymidine kinase DNA followed by ganciclovir therapy in nonhuman primates. Hum Gene Ther. 1996;7(18):2225-33.

110. Molnar-Kimber KL, Sterman DH, Chang M, Kang EH, ElBash M, Lanuti M, et al. Impact of preexisting and induced humoral and cellular immune responses in an adenovirus-based gene therapy phase I clinical trial for localized mesothelioma. Hum Gene Ther. 1998;9(14):2121-33.

111. Sterman DH, Treat J, Litzky LA, Amin KM, Coonrod L, MolnarKimber K, et al. Adenovirus-mediated herpes simplex virus thymidine kinase/ganciclovir gene therapy in patients with localized malignancy: results of a phase I clinical trial in malignant mesothelioma. Hum Gene Ther. 1998;9(7):1083-92.

112. - Sterman DH, Recio A, Carroll RG, Gillespie CT, Haas A, Vachani A, et al. A phase I clinical trial of single-dose intrapleural IFN-beta gene transfer for malignant pleural mesothelioma and metastatic pleural effusions: high rate of antitumor immune 
responses. Clin Cancer Res 2007;13(15 Pt 1):4456-4466. This paper is the first to describe the intrapleural delivery of interferon genes in human malignancy, and shows evidence of both clinical and immunological responses to single dose of vector.

113. Sterman DH, Recio A, Haas AR, Vachani A, Katz SI, Gillespie CT, et al. A Phase I Trial of Repeated Intrapleural Adenoviralmediated Interferon-beta Gene Transfer for Mesothelioma and Metastatic Pleural Effusions. Mol Ther 2010.

114. Sterman DH, Haas A, Moon E, Recio A, Schwed D, Vachani A, et al. A Trial of Intrapleural Adenoviral-mediated Interferon- \{alpha\}2b Gene Transfer for Malignant Pleural Mesothelioma. Am J Respir Crit Care Med. 2011;184(12):1395-9.

115. Selvaraj P, Yerra A, Tien L, Shashidharamurthy R. Custom designing therapeutic cancer vaccines: delivery of immunostimulatory molecule adjuvants by protein transfer. Hum Vaccin. 2008;4 (5):384-8.

116. Vachani A, Moon E, Wakeam E, Albelda SM. Gene therapy for mesothelioma and lung cancer. Am J Respir Cell Mol Biol. 2010;42(4):385-93.

117. Crystal RG. Mesothelioma: an inviting but challenging target for gene therapy. Am J Respir Cell Mol Biol. 2010;42(4):383-4. 